\title{
An outbreak of bluetongue virus serotype 9 in Southern Croatia
}

\author{
Eddy Listeš ${ }^{1}$, Sanja Bosnić², Miroslav Benić ${ }^{2}$ Josip Madić ${ }^{3}$, Željko Cvetnić2, \\ Mirko Lojkić ${ }^{2}$, Sanja Šeparovićc ${ }^{4}$, Ankica Labrovićc ${ }^{4}$, Giovanni Savini ${ }^{5}$ \\ ${ }^{1}$ Croatian Veterinary Institute, Regional Veterinary Institute Split, Croatia \\ ${ }^{2}$ Croatian Veterinary Institute, Zagreb, Croatia \\ ${ }^{3}$ Department of Microbiology and Infectious Diseases, Faculty of Veterinary Medicine, \\ University of Zagreb, Croatia \\ ${ }^{4}$ Ministry of Agriculture, Fisheries, and Rural Development, Department of Veterinary Service, Zagreb, Croatia \\ ${ }^{5}$ Istituto Zooprofilattico Sperimentale dell'Abruzzo e Molise "G. Caporale", Teramo, Italy \\ Received December 4, 2009 \\ Accepted December 14, 2011
}

\begin{abstract}
The aim of this study was to provide a description of the first epidemic of bluetongue and the first survey on midges of the genus Culicoides in Croatia. Clinical signs were firstly observed on November 2001 in sheep in Konavle, Dubrovnik - Neretva County. During this epizootic the overall sheep morbidity and mortality were $5.2 \%$ (95\% confidence interval (c.i.), 4.1-6.6\%) and $2.29 \%$ (95\% c.i., 1.6-3.3\%), respectively. After the outbreak, 3,318 serum samples of ruminants from 53 villages of the Dubrovnik - Neretva County were examined for bluetongue virus (BTV) antibodies by competitive enzyme-linked immunosorbent assay (cELISA). In forty nine $(92.45 \%, 95 \%$ c.i., $82.11-96.92 \%)$ of the 53 villages, animals with antibodies against bluetongue virus were found. In particular, a total of 178 cattle $(49.86 \%$, $95 \%$ c.i., 44.7-55.0\%), 174 sheep (13.72\%, 95\% c.i., 11.9-15.7\%) and 270 goats (15.95\%, $95 \%$ c.i., 14.3-17.8\%) were seropositive. Antibodies to bluetongue virus serotype 9 were detected in 212 positive sera by serum neutralization test. The percentage of positive animals decreased $(P>0.05)$ from the east to the west suggesting a possible east westward spreading of BTV infection. Fourteen light-trap midge collections from seven different sites were examined. Of the 4872 Culicoides spp. collected, 4,492 (92\%, 95\% c.i., 91.4-92.9\%) of them belonged to the species of Obsoletus complex. This study showed for the first time that a pathogenic strain of BTV-9, probably from Montenegro, entered Croatia causing disease and death in local sheep and that $C$. obsoletus and $C$. scoticus were likely the major vectors of infection.
\end{abstract}

BTV-9, ruminants, cELISA, serum neutralization test, culicoides, light-trap

Bluetongue (BT) is a vector-borne viral non contagious disease of ruminants caused by bluetongue virus (BTV), an RNA virus which belongs to the Reoviridae family within the Orbivirus genus (Erasmus 1975). Twenty four serotypes have been formally identified (Gibbs and Greiner 1994) and other two serotypes have been recently suggested (Hofmann et al. 2008; Maan et al. 2011).

Midges of the genus Culicoides act as biological vectors. Bluetongue virus infection might cause disease in ruminants. Symptoms are more frequent and severe in sheep (Erasmus 1975); however, a clinical form of disease might occur in goats and cattle as recently observed in Northern Europe (Saegerman et al. 2008). The main symptoms of bluetongue include increased temperature, lesions in oral mucosa, lameness, catarrhal nasal discharge, and edema of the tongue, lips, maxillomandibular space and neck (Erasmus 1975).

Before 1998, BT was recorded only occasionally in Europe (Mellor and Wittmann 2002). Since 1998, 9 different BTV serotypes (BTV-1, BTV-2, BTV-4, BTV-6, BTV-8, BTV-9, BTV-11, BTV-16) have affected countries facing the Mediterranean region and

Address for correspondence:

Eddy Listeš, DVM Phd

Croatian Veterinary Institute, Regional Veterinary Institute Split

Poljička cesta 33, 21000 Split Croatia
Phone: +385 21370752

Fax: +38521370 755

E-mail: e.listes.vzs@veinst.hr

http://www.vfu.cz/acta-vet/actavet.htm 
then, from 2006, countries of the Central and Northern Europe (Mellor and Wittmann 2002; Listes et al. 2009).

The aim of this study was to describe the first occurrence of BTV-9 in Croatia.

\section{Materials and Methods}

Following the first confirmed BT case, several surveillance measures have been implemented to control and determine the extension of the exposed area. Extensive monitoring has been carried out in sheep, goats and cattle in the areas surrounding the outbreak of BT. In the Konavle county, blood samples were collected from all ruminants whereas in the Dubrovnik and Dubrovnik Littoral counties, samples were collected randomly. The same method was used for sampling in a goat flock from the Pelješac peninsula. Because of the limited number of animals per flock, the entire village was considered as a flock.

From the end of January till June 2002, a total of 3,318 serum samples from 53 villages were collected and examined for the presence of BT virus antibodies; the number of tested animals is presented in Table 1.

Table 1. Total number of tested animals according to species and geographic area

\begin{tabular}{lcccc}
\hline Geographic area & Cattle & Goat & Sheep & Total \\
& Positive/total (\%) & Positive/total (\%) & Positive/total (\%) & Positive/total (\%) \\
\hline Dubrovnik Littoral & $11 / 60(18 \%)$ & $13 / 203(6.4 \%)$ & $9 / 179(5 \%)$ & $33 / 442(7.5 \%)$ \\
Dubrovnik & $15 / 20(75 \%)$ & $8 / 109(7.3 \%)$ & $19 / 266(7.1 \%)$ & $42 / 395(10.6 \%)$ \\
Konavle & $152 / 277(54.9 \%)$ & $245 / 1295(18.9 \%)$ & $146 / 823(17.7 \%)$ & $543 / 2395(22.7 \%)$ \\
Pelješac peninsula & 0 & $4 / 86(4.6 \%)$ & 0 & $4 / 86(4.6 \%)$ \\
Total & $178 / 357(49.8 \%)$ & $270 / 1693(15.9 \%)$ & $174 / 1268(13.7 \%)$ & $622 / 3318(18.7 \%)$ \\
\hline
\end{tabular}

A commercial competitive enzyme-linked immunosorbent assay (cELISA, Veterinary Medical Research \& Development, Inc., Pullman, WA, USA) was used to detect BT antibodies in serum samples. To identify the BT virus serotype involved and determine the titres of BT virus antibodies, c-ELISA positive serum samples were further tested by the serum-neutralisation assay (Listeš et al. 2009) at the Virology Department, Istituto Zooprofilattico Sperimentale dell'Abruzzo e Molise (IZSA\&M) “G. Caporale”, Teramo, Italy, OIE Reference Laboratory for BT. Positive and negative controls for serum neutralization were provided by the OIE Reference Laboratory of the Onderstepoort Veterinary Institute, South Africa.

One sheep from the village Gruda, Konavle area, with severe signs of the disease was euthanised. At necropsy, liver, spleen and lymph-node samples were collected, stored in $10 \%$ buffered formalin solution and subsequently processed for BTV detection by using the reverse-transcriptase polymerase chain reaction (RT-PCR) (Parsonson and McColl 1995).

Spleen and mesenterial lymph-node samples were stored for 4 years in $10 \%$ formalin before examination. The samples were first washed three times in PBS to remove formalin, then $1 \mathrm{~g}$ of spleen and $1 \mathrm{~g}$ of lymph-node were homogenized by adding $1 \mathrm{ml}$ of PBS and using a sterile mortar and pestle. The two tissue samples were analyzed in separate. Then, $500 \mathrm{ml}$ of each minced organ were transferred to $1.5-\mathrm{ml}$ Eppendorf tubes and frozen at $-20^{\circ} \mathrm{C}$. A homogeneous portion of each tissue was thawed and incubated with protease $\mathrm{K}$ (final concentration of $50 \mathrm{ml} / \mathrm{ml}$ ) and Sodium Dodecyl Sulphate (SDS) (final concentration of 0.1\%). Viral RNA extraction was performed by use of TRIzolÔ reagent according to the method described elsewhere (Chomczynski and Sacchi 1987).

One-step RT-PCR with BT9R and BTB primers, as described by Katz et al. (1993) were used in the study. The primers amplify a part of the region encoding non-structured NS1 in viral RNA segment 5 . The primers were

Table 2. Sites of collection of Culicoides made in September 2002

\begin{tabular}{lccc}
\hline County & Location & Animal hosts in the stables & Number of collection \\
\hline Split-Dalmatia & Brštanovo & sheep & 1 \\
Split-Dalmatia & Čiovo & sheep & 1 \\
Dubrovnik-Neretva & Brsečine & sheep, goats, cattle & 4 \\
Dubrovnik-Neretva & Komolac & goats, cattle & 5 \\
Dubrovnik-Neretva & Pridvorje & sheep & 1 \\
Dubrovnik-Neretva & Čilipi & goats & 1 \\
Dubrovnik-Neretva & Molunat & sheep & 1 \\
\hline Total & & & 14 \\
\hline
\end{tabular}


used in reaction concentration of $0.6 \mathrm{pmol} / \mathrm{ml}$. RNA was denatured by methyl-mercury hydroxide, as described by Wade-Evans et al. (1990) and used as a basis for cDNA synthesis. The One-Step RT-PCR kit (QIAGEN, Germany) was used for the reaction of reverse transcription and amplification. The temperature setting was as follows: $30 \mathrm{~min}$ at $48{ }^{\circ} \mathrm{C}, 10 \mathrm{~min}$ at $95^{\circ} \mathrm{C}, 40$ cycles at $94{ }^{\circ} \mathrm{C}$ for $15 \mathrm{~s}, 60{ }^{\circ} \mathrm{C}$ for $30 \mathrm{~s}, 72{ }^{\circ} \mathrm{C}$ for $30 \mathrm{~s}$, and final extension at $72{ }^{\circ} \mathrm{C}$ for $7 \mathrm{~min}$. Electrophoresis was performed on $1.5 \%$ agarose gel.

The entomological survey was carried out in collecting sites of two counties of southern Dalmatia: Split Dalmatia and Dubrovnik - Neretva (Table 2).

Insect collection was performed by using Onderstepoort black light-traps $(220 \mathrm{~V}, 8 \mathrm{~W})$ placed close to the sheep, goats and cattle farms. In September 2002, the traps were active from the sunset till the sunrise at seven locations in Dubrovnik - Neretva County. In 14 cases midges were collected. They were then identified according to the protocols of the OIE Reference Laboratory for BT at IZSA\&M and kept in 70\% ethanol.

The prevalence levels in animals were calculated through a Bayesian approach using the Beta $(\mathrm{s}+1, \mathrm{n}-\mathrm{s}+1)$ distribution where $s$ is the total number of positives and $n$ is the total number of tested animals (Sivia 1996). The probability distribution of the percentage of positive animals shows not only the most probable value of prevalence, but also the level of uncertainty due to sample size. Upper and lower interval limits at $95 \%$ confidence level were also calculated.

\section{Results}

In November 2001, clinical symptoms indicative of BT were observed in sheep flocks in Konavle, the southernmost area of Croatia bordering on Montenegro and Bosnia and Herzegovina. The symptoms included excessive drooling, oedema of the maxillomandibular space, tongue and cheek, oral mucosa erosions, and elevated body temperature of up to $40.7^{\circ} \mathrm{C}$. Reddened coronary hoof band with consequential lameness and sporadic abortion in late gestation sheep were also recorded. In the Konavle area, 51 sheep showed BT clinical signs. The morbidity was $6.2 \%(51 / 823$, $95 \%$ confidence interval (c.i.), 4.7-8.1\%) whereas the mortality $2.79 \%(23 / 823,95 \%$ c.i., $2.1-4.4 \%$ ). In the Dubrovnik area 15 sheep were sick, in this county the morbidity was $5.64 \%(15 / 266,95 \%$ c.i., $3.5-9.1 \%)$ and the mortality $2.25 \%(6 / 266,95 \%$ c.i., 1.1-4.8\%). The overall sheep morbidity and mortality during BT epizootic was $5.2 \%$ (66/1268, 95\% c.i., 4.1-6.6\%) and 2.29\%,(29/1268, 95\% c.i., 1.6-3.3\%), respectively. No symptoms were observed in cattle whereas three cases were reported in goats. In these animals the symptoms were similar to those observed in sheep but much less severe.

Seropositive animals were detected in 49 flocks, yielding $92.45 \%$ (95\% c.i., 82.11$96.92 \%)$, of infected flocks. Of the 3,318 serum samples tested, $622(18.7 \%, 95 \%$ c.i., $17.5-20.1 \%)$ were positive to BTV c-ELISA, namely 178 cattle $(49.86 \%, 95 \%$ c.i., 44.7-55.0\%), 174 sheep (13.72\%, 95\% c.i., $11.9-15.7 \%)$ and 270 goats $(15.95 \%, 95 \%$ c.i., 14.3-17.8\%). Antibodies to serotype 9 were detected by MTSN in 212 positive sera. Comparison of the species seroprevalence revealed a higher $(P<0.05)$ seroprevalence in cattle $(49.86 \%)$ compared to that observed in goats $(15.95 \%)$ and sheep $(13.72 \%)$. A higher prevalence of BTV was found in cattle $(54.87 \%$ and $75 \%)$ and sheep $(17.74 \%$ and $7.34 \%)$ of Konavle and Dubrovnik, respectively. In contrast, more $(P<0.05)$ BTV positive goats $(18.92 \%)$ were observed in Konavle compared to the other three areas included in the study (Fig. 1).

The PCR method performed on tissue sections, detected presence of BTV RNA. However, the very small amount of the amplified product did not allow any sequencing and molecular characterization.

Culicoides were identified on the basis of their wing pattern, and the findings were confirmed at the IZSA\&M. Fourteen insect catches were obtained from the entomological survey. Of a total of 44,008 insects collected, 4,872 were identified as Culicoides spp. and 4,492 (92\%) of them belonged to the species of the Obsoletus complex: C. obsoletus, C. scoticus. Other Culicoides species such as C. circumscriptus, C. paolae, C. punctatus, species of the Pulicaris complex, $C$. seavanicus, $C$. fascipennis, $C$. haranti and $C$. fagineus were also identified. Culicoides $C$. obsoletus and $C$. scoticus were the most widespread 


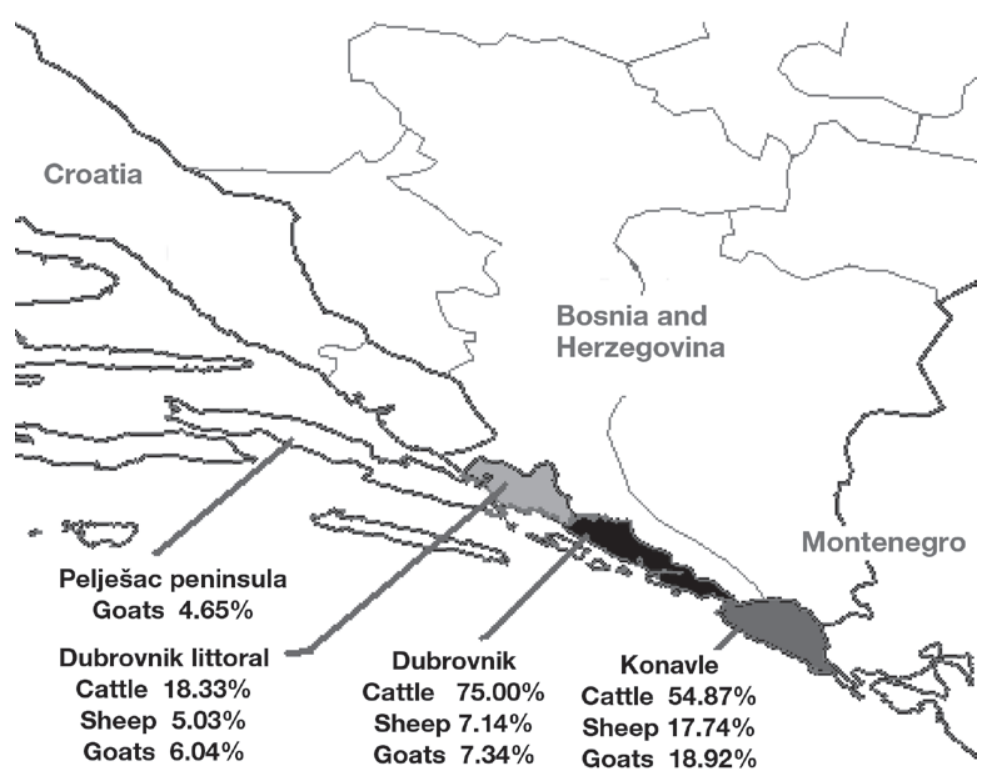

Fig. 1. Bluetongue prevalence in ruminants in Dubrovnik - Neretva County.

species, being recorded in all sites except on the island of Čiovo (Split - Dalmatia county). The mean air temperature at the time of the study was $20^{\circ} \mathrm{C}$.

\section{Discussion}

We reported the first occurrence of BT in Dubrovnik - Neretva County in the southernmost part of Croatia. The area lies at $52 \mathrm{~m}$ above sea level, $42^{\circ} \mathrm{N}$. During the years $1993-2002$, the mean daily air temperature in the area in September was $21.3^{\circ} \mathrm{C}$, mean air humidity $61.4 \%$, and mean monthly precipitation $90.8 \mathrm{~mm}$. Bluetongue virus was demonstrated clinically, and confirmed by serology and virology. The Croatian strain was pathogenic and capable of causing disease and death in sheep, mild sporadic symptoms in goats but resulting completely asymptomatic in cattle. The clinical signs were in line with those described in sheep by Erasmus (1975).

The infection which involved most $(92.45 \%)$ of the Southern Croatian flocks was not uniformly spread. More cattle (49.86\%) were found infected compared to goats $(15.95 \%)$ and sheep (13.72\%) This supports the hypothesis that insects prefer to feed on cattle (Bowne et al. 1966) which, in other words could mean that BTV multiplied initially in cattle and subsequently it was transmitted to sheep and goats (Parsonson 1992). The presence of BTV-9 neutralising antibodies in $212 \mathrm{c}$-ELISA positive sera proved that BTV-9 was the serotype responsible for the Croatian outbreaks. The fact that the BTV-9 infection was reported in Turkey, Greece, Bulgaria, Macedonia, Serbia and Montenegro (Mellor and Wittmann 2002), and later also in Albania, and Bosnia and Herzegovina suggests that BTV-9 reached Croatia via eastern arm of the epizootic circulating in the Mediterranean basin.

It appears quite conceivable that BT was transferred by infected Culicoides or animals from the neighbouring Serbia and Montenegro as the prevalence of seropositive animals 
in this study declined from the east westwards. The highest proportion of seropositive animals were recorded in Konavle, followed by Dubrovnik, Dubrovnik Littoral and Pelješac peninsula. The significant difference in the prevalence of seropositive animals between particular areas suggests that the infection likely spread westwards.

Among the Culicoides caught, the predominant species were those of the Obsoletus complex, in particular C. obsoletus and C. scoticus (92\%). Species of the Obsoletus complex have already been associated to BTV transmission. Bluetongue virus was isolated from C. obsoletus in Cyprus (Mellor and Pitzolis 1979) and in Italy (Savini et al. 2005). Other species were also identified in the outbreak areas: C. circumscriptus, C. paolae, C. punctatus, C. seavanicus, C. fascipennis, C. haranti and C.fagineus, and C. pulicaris, a species belonging to the Pulicaris complex. Among these species, C. pulicaris could be a possible BTV vector (Caracappa et al. 2003). The identified species $C$. circumscriptus, C. pulicaris, C. seavanicus, C. fascipennis and C. fagineus were also found in Greece in 1983 (Mellor et al. 1984), whereas C. paolae is a new species recently recorded in Southern Italy (Boorman et al. 1996).

Analysis of climate data has been used to predict the potential distribution of $C$. imicola in Europe, revealing the possibility for $C$. imicola to spread from Greece and Italy to some parts of the Croatian Littoral as well as to the littoral areas of Albania, Serbia, Montenegro, and Bosnia and Herzegovina (Wittmann et al. 2001), which was not demonstrated in the present study. In conclusion, a pathogenic strain of BTV-9, probably from Montenegro, entered Croatia infecting ruminants and causing disease and death in local sheep. As no C. imicola was caught, the major role of transmitting the infection might have been played by $C$. obsoletus and C. scoticus.

\section{References}

Boorman J, Mellor PS, Scaramozzino P 1996: A new species of Culicoides (Diptera, Ceratopogonidae) from southern Italy. Parassitologia 38: 501-503

Bowne JG, Luedke AJ, Foster NM, Jochim MM 1966: Current aspect of bluetongue in cattle. J Am Vet Med Assoc 148: 1177-1180

Caracappa S, Torina A, Guercio A, Vitale F, Calabro A, Purpari G, Ferrantelli V, Vitale M, Melor PS 2003: Identification of a novel bluetongue virus species of Culicoides in Sicily. Vet Rec 153: 71-74

Chomczynski P, Sacchi N 1987: Single-step method of RNA isolation by acid guanidinium thiocyanate-phenolchloroform extraction. Anal Biochem 162: 156-159

Erasmus BJ 1975: Bluetongue in sheep and goats. Aust Vet J 51: 165-170

Gibbs EP, Greiner EC 1994: The epidemiology of bluetongue. Comp Immunol Microbiol Infect Dis 17: $207-220$

Hofmann MA, Renzullo S, Mader M, Chaignat V., Worwa G, Thuer B 2008: Genetic characterization of toggenburg orbivirus, a new bluetongue virus, from goats, Switzerland. Emerg Infect Dis 14: 1855-1861

Katz JB, Gustafson GA, Alstad AD, Adler KA, Moser KM 1993: Colorimetric diagnosis of prolonged bluetongue viremia in sheep, using an enzyme-linked oligonucleotide sorbent assay of amplified viral nucleic acids. Am J Vet Res 54: 2021-2026

Listeš E, Monaco F, Labrović A, Paladini C, Leone A, Di Gialleonardo L, Camma C, Savini G 2009: First evidence of bluetongue virus serotype 16 in Croatia. Vet Microbiol 138: $92-97$

Maan S, Maan NS, Nomikou K, Veronesi E, Bachanek-Bankowska K, Belaganahalli MN, Attoui H, Mertens PPC 2011: Complete genome characterisation of a novel 26th bluetongue virus serotype from Kuwait. PLoS ONE 6: e26147. doi:10.1371/journal.pone.0026147

Mellor PS, Wittmann EJ 2002: Bluetongue virus in the Mediterranean basin 1998- 2001. Vet J 164: 20-37

Mellor PS, Pitzolis G 1979: Observations on breeding sites and light-trap collections of Culicoides during an outbreak of bluetongue in Cyprus. Bull Entom Res 69: 229-234

Mellor PS, Jennings M, Boorman JPT 1984: Culicoides from Greece in relation to the spread of bluetongue virus. Rev Elev Med Vet Pays Trop 37: 286-289

Parsonson IM 1992: Overview of bluetongue virus infection of sheep. In: Proc 2nd Int Symp Bluetongue, Paris, France, pp 713-724

Parsonson IM, McColl KA 1995: Retrospective diagnosis of bluetongue virus in stored frozen and fixed samples using PCR. Vet Microbiol 46: 143-149

Savini G, Goffredo M, Monaco F, Di Gennaro A, Cafiero Ma, Baldi L, De Santis P, Meiswinkel R, Caporale V 2005: Bluetongue virus isolations from midges belonging to the Obsoletus complex (Culicoides, Diptera: Ceratopogonidae) in Italy. Vet Rec 157: 133-139 
Saegerman C, Berkvens D, Mellor PS. 2008: Bluetongue epidemiology in the European Union. Emerg Infect Dis 14: $539-544$

Sivia DS, 1996: Data analysis. A Bayesian tutorial. Oxford University Press. New York, USA

Wade-Evans AM, Mertens PPC, Bostock CJ 1990: Development of the polymerase chain reaction for detection of the bluetongue virus in tissue samples. J Virol Methods 30: 15-24

Wittmann EJ, Mellor PS, Baylis M 2001: Using climate data to map the potential distribution of Culicoides imicola (Diptera: Ceratopogonidae) in Europe. Rev Sci Tech Off Int Epiz 20: 731-740 